\title{
Dying Hungry: Nazi Ideology and the Pragmatism behind Starvation in Implementing the Final Solution
}

\author{
Kiril Feferman
}

Ariel University

\begin{abstract}
German theories and policies regarding the relationship between food and Jewish citizens of eastern Europe served as an important foundation of the Nazis' Judenpolitik during the Holocaust (1933-45). The mass starvation of Jews in Germandominated Europe was the result of a carefully calculated policy to make the Jews pay for a long list of misfortunes they had allegedly inflicted on the Germans. This policy evolved from a highly restrictive and discriminatory approach toward German Jews, which unfolded against a backdrop of harsh food policies applied to the local non-Jewish population.
\end{abstract}

Keywords: food, malnutrition, starvation, Holocaust, war.

INTRODUCTION

W

eaponizing food supplies to achieve political and military goals is a relatively widespread phenomenon in human history, and, along with Hitler's racist ideology, explains German food policies toward Jews during World War II (Oberschall and Seidman; De Waal 94-112). The Nazis' position was that there was no room for Jewish existence in the Germandominated world and this goal must be achieved as quickly as possible (Browning 374-423). Food was in short supply in the German Reich even prior to the German invasion of the Soviet Union in 1941, and the longer the war dragged on, the more acute the food problem became.

These were the considerations put forth by some of the economic experts who participated in a high-level gathering in Berlin on 2 May 1941. The meeting included General Georg Thomas, Wehrmacht supreme "economic" officer, and was convened to determine food policy for the occupied Soviet territories (Kay 697). Pragmatic considerations might have been to feed some of the Jews in order to extend the Jewish forced labour in the German war machine.

However, the pragmatists were not the only actors determining the contours of German food policies toward the Jews. Notable among them were some "old fighters" in the Nazi movement, who contended that the Jews would have to be starved precisely because of how they had behaved toward 
the German population during World War I, which, they claimed, ultimately brought about the German collapse (Cory 128-30). ${ }^{1}$

Nazi Germany's food policies reflected approaches advocated by German ideologists and pragmatists. This article outlines the Nazis' views on the food factor vis-à-vis Jews prior to the Nazi seizure of power in Germany in January 1933, before the onset of World War II, during the war on the territory of the German Reich, and in the Polish and Soviet territories under German control. Special emphasis is placed on the impact of German food policies on Jewish society.

\section{NAZI VIEWS ON JEWS AND THE FOOD SITUATION IN GERMANY}

Prior to their ascent to power, Nazi ideologists, including Hitler, had declared that there was a relationship between the food situation and the Jewish question. Their stance can be traced back to the noticeable deterioration in the food situation in Kaiser Germany during World War I (see, for example, Davis, especially 170-216; and Allen). From the Nazi perspective, this development did not come about spontaneously, or as a result of poor planning, or from the Allies' blockade as is often assumed in scholarship (Braun 25-26). The Nazis suspected that German Jews were actively involved in and benefitting from the food deficit and the flourishing black market. The Nazis posited that it was the growing dissatisfaction of ordinary German civilians with wartime hardships, including food deficits, that eventually brought about the collapse of the German home front and the humiliating defeat of the country in World War I (Götz 30).

The Nazis drew several lessons from this "Great War." First, a proper food procurement system was recognized as a factor of paramount importance to the resilience of the home front and to secure victory in the war overall. Second, all means were justifiable to avoid the erosion of civilian morale that would follow from a deterioration in the availability of food. Third, other peoples would have to pay for the well-being of Germans.

Among the other peoples, Jews were singled out to suffer particularly from Nazi food policies, in keeping with Nazi racial doctrine. Nazi fanatics contended that Jews bore the principal responsibility for the German defeat in World War I and hence should be punished by starvation, as the Jews were accused of employing starvation against the German civilian population. Thus, an agreement was reached between Nazi pragmatists and Nazi fanatics, who had differing approaches to food policy concerning the Jews.

\footnotetext{
1 The most prominent was Herbert Backe, who in 1942 became the Staatssekretär for the Ministry for Food, and in 1944, for the Ministry of Agriculture.
} 


\section{NAZI GERMANY}

When the Nazis rose to power in 1933, the aforementioned theoretical considerations became translated into policy. The new Nazi government had to tackle a grave food crisis that brought people to the point of hunger, and a vow to eliminate hunger was one of its most important promises. The Nazi food policy frequently overlapped with their promise to rid the German nation of Jews (Weinreb 50); however, their propaganda described the current hunger as a weapon wielded by the Jews (Weinreb 52). A study published in 1937 by Richard Darré, German Minister of Food and Agriculture, considered the elimination of German Jews against the background of the country's autarchic food policies (Weinreb 58). A serious phase of discrimination in food policy was reached as the German state ramped up for war in August 1939, when rationing was introduced throughout the German Reich. Predictably, the policy was predicated on Nazi racial-biological ideology that presumed a racial pecking order.

As a result, German Jews were confronted with increasing discrimination in food rations in various forms, some depending on local decision-makers, others centrally orchestrated. This included inter alia higher prices, lower rations, and restrictions on the hours that Jews were allowed to shop in food stores (Kaplan 150-51). A corollary of this policy was a growing popular enmity toward Jews shopping amidst Germans (Kaplan 33-34). Nonetheless, unlike in Eastern Europe, there is no record of starvation among German Jews during World War II because the overall level of food provisions delivered to the population in Germany was considerably higher than elsewhere in Europe, especially in eastern Europe. In addition, in conducting its Jewish policies in the Reich, the German government avoided creating situations that would risk alienating the local population. This included avoiding the starvation of the Jews in Germany (see, for example, Cesarani 149).

\section{OCCUPIED POLAND}

The situation was markedly worse for the Jews in German-occupied Poland, where they were rounded up and incarcerated in ghettos. German policies toward Jews evolved as a result of constant interactions and disputes in the German administration between those eager to capitalize on Jewish labour and those willing to facilitate the total extraction of Jewish wealth through the leverage of deliberate starvation (Browning 113). Thus, the German policies in occupied Poland reflected old disagreements between the ideologists and the pragmatists. 
German orders for occupied Poland stipulated that, in terms of calories, each Jew was entitled to roughly what a prisoner of war could expect, which was half of what was allocated to Poles. As a result, even the most privileged Jews in the community, whether incarcerated in ghettos or in civilian camps, were doomed to starvation (Janczewska; see also Roland 99-104). Every free Jew had now the same aim of every prisoner of Nazi camps: to procure food. This was difficult all over German-dominated Europe, as food was becoming increasingly scarce (Obenaus). However, the situation in German-controlled Poland was considerably worse than elsewhere, except for the occupied Soviet territories (excluding the former Baltic states) (Kroener et al. 37677).

The growing danger of starvation led to appalling inequality in Jewish society in the ghettos and camps. Judenrat officials were entitled to 1,665 calories per day, which was high compared to the entitlement of other ghetto inhabitants, but still considerably below the survival level of 2,400 calories. Those working during the day needed 3,000 calories to maintain their health. These privileged Jews were uniquely placed to abuse their positions and to extort bribes from other Jews. The tiny stratum of wealthy Jews also fared well in the ghettos. Consequently, a small minority of Jews experienced a certain degree of feast amidst famine. This feast continued until the beginning of the large-scale deportations from the ghettos to death camps in occupied Poland that started in the summer of 1942.

Jewish refugees from other locations within Poland were at the bottom of the nutrition, or to be more precise, malnutrition ladder; ${ }^{2}$ they were entitled to 807 calories per day. Farther below were the unemployed, who received still less. To survive, people in these categories needed to supplement their rations; otherwise, they were on a fast track to starvation, and frequently became the first Jews to perish in the ghettos.

Theoretically, work was the only way for a Jew imprisoned in a ghetto or a camp to survive. Work not only protected Jews from deportation, it entitled them to higher food rations (Gruner). Yet, on closer examination, it turns out that Jews lawfully employed received only 1,220 calories per day, that is, far below the minimum needed for survival. Privileged categories of the Jewish population, such as Jewish police and very skilled workers, were entitled to increased rations (and there were free meals for children), but even the privileged needed more than their rations to ensure their survival and that of their families. In order to survive, everyone in the ghetto, except perhaps the wealthiest and the highest stratum of the Judenrat bureaucrats, needed to augment their rations somehow.

2 Every region was assigned one ghetto, and Jews from all over the region were assembled there. 
The most widespread method of accessing more food was to become involved in food smuggling. This entailed breaking the law and was fraught with mortal danger, as the guards (either Polish or German) shot freely at those caught smuggling. If food smugglers were fortunate enough to avoid the guards, they could be seized by Jewish policemen who could turn them over to local or German police, or in the best case, content themselves with extorting a bribe.

Despite these risks, the food conditions were so appalling that increasing numbers of Jews in the ghettos saw smuggling as their only chance of survival. The natural outcome of the Jewish demand for food and the supply offered by the local population, primarily peasants, was the development of a black market (Kochanowski). Jews thus sold or exchanged their personal belongings in this illegal market for food at prices that reflected the inadequate food supply in the General Government. Pressure on the food supply was augmented by the arbitrary requisitioning of troops and private purchases by members of the occupying power (Kroener et al. 378-79).

Official German opposition to the black market served to further increase the price of produce, as locals assessed and factored in the risks involved in selling foodstuffs to Jews. Finally, prices, or the exchange rate, for food depended on availability (unavailability in the ghettos). Consequently, Jews had to pay increasingly exorbitant prices for food, while those able to produce food, primarily peasants, benefitted.

Because of their small size, children carried out most of the food smuggling; they were able to penetrate through small openings in the walls surrounding the ghettos. Thus, Jewish child smugglers began to provide food for themselves, and eventually for their families. The new role of children as providers for their families should be contrasted with the inability of their parents to provide not only for themselves but also for their children-a development unprecedented in Jewish history, and perhaps in world history. As a result of a reversal of the natural order, the family as a solid institution and a cornerstone of society dissolved or collapsed in the ghettos.

Another widespread method of obtaining extra food was by denouncing other ghetto inhabitants, whether to the ghetto authorities or to the Gestapo. However, the price received for a denunciation was low.

Finally, the incessant search for more food led to a sharp decline in moral values among ghetto and camp prisoners. Youth crime increased dramatically. Theft and prostitution, especially among the adolescents, gained currency. Moreover, ghetto inhabitants frequently refused to report to the authorities the deaths of household members in a timely fashion in order to continue receiving food rations meant for the deceased person, essentially a desecration of the dead. 
Although smuggling grew significantly, it failed to solve the food problem for many ghetto inhabitants. A sharp deterioration in the food situation was noticeable everywhere in the ghettos and camps, and its most visible manifestations were a rapid increase in the mortality rate and public indifference to corpses lying in the streets. On 17 May 1941, a German Foreign Ministry representative attached to the Fourth Army reported the situation in the Warsaw ghetto: "the incidence of death from starvation increased massively. Weakened, emaciated to skeletons, women, men, and children are lying about the pavements with distorted faces" (Kroener et al. 379). The problem of malnutrition haunted everyone. Judging by contemporary accounts, all people could think about was the ache in their stomachs and where they might find something to eat (Goldenberg 166-69).

Outside of the ghettos, in cases where Jews were rescued, their rescuers had to provide food for the Jews in their shelters. The inability or reluctance of a potential rescuer to procure food was tantamount to a death sentence for these Jews (Michlic).

\section{OCCUPIED SOVIET TERRITORIES}

Territories that Nazi Germany occupied in the course of its invasion of the Soviet Union were administered as colonies, which meant they received even harsher treatment than other areas under German control (Lower 1829). The policy was grounded in the need to mobilize maximum resources to provide the fighting forces and the homeland with urgently needed raw materials and foodstuffs. Given the expected exacerbation of shortages in the Reich in the autumn of 1941, the Wehrmacht intended to occupy the Soviet wheat-producing regions and maintain operations largely by living off the land (Müller, "From Economic Alliance" 140-41). This policy was reiterated on several occasions by the highest civil and military authorities of the Reich (Müller, "From Economic Alliance" 174-75).

To achieve these goals, the urban populations of the western Soviet Union and Ukraine were to be starved, including, first and foremost, the Jews (Kay). The destruction of the Jews was regarded by Nazi pragmatists as necessary to rid the territories under German control of "surplus mouths." These notions were succinctly expressed in a report sent on 2 December 1941 by Professor P. H. Seraphim, a logistics expert in Ukraine, to General Thomas from the Wehrmacht Economic Department: 
The creaming-off of agricultural surpluses from the Ukraine as food supplies for the Reich is only conceivable if trade in the Ukraine is pushed down to a minimum. Efforts to achieve this will be made by:

1. Eradicating surplus mouths (Jews, and the population of the large Ukrainian cities) which, like Kyiv, will receive no quota of supplies. (Burleigh 221)

Certainly, there were differences in German approaches to food policy depending on specific local conditions, yet several basic assumptions hold true. German plans regarding food provisioning were realized to no small extent in the occupied Soviet territories (Berkhoff 164-86; see also Burleigh). However, there were exceptions, primarily in the former Baltic states (Kroener et al. 382) and the northern Caucasus (Feferman, "The Food Factor" 87-90), which were singled out for political, strategic, or ideological reasons.

How did the realization of the German plans affect the unfolding of the "Final Solution" in the occupied Soviet areas? Often in areas where German plans were implemented, food scarcity for the entire civil population under German control soon reached a critical point, necessitating drastic decisions, as inaction could prompt enormous opposition to German rule. One solution was to procure food for the entire civil population, but this ran counter to the stance of Nazi ideologues and pragmatists alike (Gerlach 265-88). The elimination of "surplus mouths" was the solution Nazi decision-makers initially came up with, a solution that involved provisioning the local population with food below the subsistence level. This was the case on the Crimean Peninsula in November-December 1941 (Feferman, "The Food Factor" 78-84) where it received the full support of General Erich von Manstein, the highest German military authority in the region: "The food situation in our Fatherland requires that the troops be supplied with food from local resources and, furthermore, that as much stocks as possible be put at the Fatherland's disposal .... A considerable part of the population of the enemy's towns will have to starve" (Feferman, The Holocaust 238).

It was assumed that local people would be able to live off their own resources, as they were able to significantly augment these resources by looting abandoned Soviet storage facilities and food stores during the interim period (after the Red Army left but before the Wehrmacht entered). Such incidents did take place, but their significance should not be overrated because the retreating Soviet forces, acting on the orders of the high command, either destroyed food storage locations or took considerable food stocks with them. These facts were known to local people and widely employed by Nazi propaganda, which reiterated that only Bolsheviks bore responsibility for the miserable food conditions in the occupied territories. According to a German military expert in Reichskommissariat Ukraine in 
November 1941, German food policy in the Reichskommissariat was tantamount to the "extermination of Jews" (Berkhoff 167).

Later, when the situation at the fronts worsened, the Germans departed from their rigid, ideologically driven policies and increased the food supply by deporting a portion of the urban population to the countryside (Kroener et al. 383). Yet, this moderate phase was of little relevance to the local Jews, who were mostly murdered by that time. In areas of the Soviet Union where mass murders were carried out early on, German food policies did not have time to impact the Jewish population. However, in places where the Germans allowed a more protracted Jewish existence in the ghettos (such as in Kaunas, Vilnius, and Minsk), local Jews went through sufferings similar to Jews in Poland (Aleksiun). The introduction of maximum rations in towns on 4 November 1941, illustrates the inadequate, in fact starvation-level, food provisioning policy. The nutritional value of these rations was about 1,200 calories per day for those doing "useful work," roughly 850 calories for those not employed in German projects, and 420 calories for children under the age of 14 and for Jews (Müller, "The Failure" 1163). Moreover, even these meagre rations were issued only if the German authorities decided that the local population had exhausted its stocks, and provided that deliveries to the Reich were not affected. These were starvation rations for most non-Jews, but the Jews were usually the first to perish, as their allocation was the lowest.

\section{CONCLUSION}

German theories and policies regarding Jews and food constituted one of the most important foundations of the Nazis' Judenpolitik. The mass starvation of Jews in German-dominated Europe was the result of a carefully calculated policy. The Germans aspired to murder the Jews, but their deaths were not to be easy; through attrition and starvation the Jews had to pay for a long list of misfortunes they had allegedly inflicted on the Germans. This policy evolved from a highly restrictive and discriminatory approach toward German Jews in the Reich to a full-fledged starvation policy applied to the Jews in eastern Europe, which unfolded against the backdrop of very harsh food policies applied to the local non-Jewish population. 


\section{Works Cited}

Aleksiun, Natalia. "Food, Money and Barter in the Lvov Ghetto, Eastern Galicia." Coping with Hunger and Shortage under German Occupation in World War II, edited by Tatjana Tönsmeyer et al., Palgrave Macmillan, 2018, pp. 223-47.

Allen, Keith. "Sharing Scarcity: Bread Rationing and the First World War in Berlin, 1914-1923." Journal of Social History, vol. 32, no. 2, 1998, pp. 371-93. DOI: $10.1353 / \mathrm{jsh} / 32.2 .371$

Berkhoff, Karel C. Harvest of Despair: Life and Death in Ukraine under Nazi Rule. Belknap Press, 2004.

Braun, Hans-Joachim. The German Economy in the Twentieth Century. Routledge, 1990.

Browning, Christopher R. The Origins of the Final Solution: The Evolution of Nazi Jewish Policy, September 1939-March 1942. Nebraska UP and Yad Vashem, 2004.

Burleigh, Michael. Germany Turns Eastwards. A Study of Ostforschung in the Third Reich. Cambridge UP, 1988.

Cesarani, David. Final Solution: The Fate of the Jews 1933-1949. Macmillan, 2015.

Cory, Brant Wamick. The Food Crisis in Germany and Its Consequences, 1918-1924. 1999. Virginia Commonwealth University, MA thesis.

Davis, Belinda Joy. Home Fires Burning: Food, Politics, and Everyday Life in World War I Berlin. North Carolina UP, 2000.

De Waal, Alex. Mass Starvation: The History and Future of Famine. Polity Press, 2018.

Feferman, Kiril. "The Food Factor as a Possible Catalyst for Holocaust-Related Decisions: The Crimea and the North Caucasus." War in History, vol. 15, no. 1, 2008, pp. 72-91. DOI: 10.1177/0968344507083994

---. The Holocaust in the Crimea and the North Caucasus. Yad Vashem, 2016.

Gerlach, Christian. Kalkulierte Morde: Die deutsche Wirtschafts- und Vernichtungspolitik in Weißrußland 1941 bis 1944. Hamburger Edition, 1999.

Goldenberg, Myrna. "Food Talk: Gendered Responses to Hunger in the Concentration Camps." Experience and Expression: Women, the Nazis, and the Holocaust, edited by Elizabeth R. Baer and Myrna Goldenberg, Wayne State UP, 2003, pp. 161-79.

Götz, Aly. Hitler's Beneficiaries: Plunder, Racial War, and the Nazi Welfare State. Metropolitan Books, 2007.

Gruner, Wolf. Jewish Forced Labor under the Nazis: Economic Needs and Racial Aims, 1938-1944. Cambridge UP, 2006.

Janczewska, Marta. "Research on Starvation in the Warsaw Ghetto-Ethical Dilemmas." Holocaust Studies and Materials, vol. 2, 2010, pp. 439-50.

Kaplan, Marion A. Between Dignity and Despair: Jewish Life in Nazi Germany. Oxford UP, 1998.

Kay, Alex J. "Germany's Staatssekretäre, Mass Starvation and the Meeting of 2 May 1941." Journal of Contemporary History, vol. 41, no. 4, 2006, pp. 685-700. DOI: 10.1177/0022009406067750

Kochanowski, Jerzy. "Black Market in the General Government 1939-1945: Survival Strategy or (Un)Official Economy?" Coping with Hunger and Shortage under German Occupation in World War II, edited by Tatjana Tönsmeyer et al., Palgrave Macmillan, 2018, pp. 27-47. 
Kroener, Bernhard R., et al., editors. Germany and the Second World War. Vol. 5: Organization and Mobilization of the German Sphere of Power, part 1: Wartime Administration, Economy, and Manpower Resources, 1939-1941. Clarendon Press, 2000.

Lower, Wendy. Nazi Empire-Building and the Holocaust in Ukraine. North Carolina UP, 2005.

Michlic, Joanna. "Stories of Rescue Activities in the Letters of Jewish Survivors about Christian Polish Rescuers, 1944-1949." Warsaw: The Jewish Metropolis. Essays in Honor of the 75th Birthday of Professor Antony Polonsky. Edited by Glenn Dynner and François Guesnet, Brill, 2015, pp. 515-38. IJS Studies in Judaica 15.

Müller, Rolf-Dieter. "From Economic Alliance to a War of Colonial Exploitation." The Attack on the Soviet Union, edited by H. Boog et al., Oxford UP, 1998, pp. 118-224.

---. "The Failure of the 'Economic Blitzkrieg' Strategy." The Attack on the Soviet Union, edited by H. Boog et al., Oxford UP, 1998, pp. 1081-1244.

Obenaus, Herbert. "Hunger und Überleben in den nationalsozialistischen Konzentrationslagern (1938-1945)." Der Kampf um das tägliche Brot; Nahrungsmangel, Versorgungspolitik und Protest, 1770-1990, edited by Manfred Gailus and Heinrich Volkmann, Westdeutscher Verlag, 1994, pp. 361-76.

Oberschall, Antony, and Michael Seidman. "Food Coercion in Revolution and Civil War: How They Do It." Comparative Study of Society and History, vol. 47, no. 2, 2005, pp. 372-402. DOI: 10.1017/S0010417505000174

Roland, Charles G. Courage under Siege: Starvation, Disease, and Death in the Warsaw Ghetto. Oxford UP, 1992.

Weinreb, Alice. Modern Hungers: Food and Power in Twentieth-Century Germany. Oxford UP, 2017. 